\title{
Thermal dependence in seed germination of Diospyros inconstans Jacq. (Ebenaceae)
}

Edvânia da Silva Carvalho ${ }^{1 *} \odot$, Manuela Oliveira de Souza ${ }^{1} \odot$, Darlene Pereira da Silva ${ }^{1} \odot$, Marcus Dhilermando Hora de Souza' ${ }^{1}$, Andrea Vita Reis Mendonça ${ }^{1} \odot$

${ }^{1}$ Universidade Federal do Recôncavo da Bahia, Cruz das Almas, BA, Brasil. E-mail: edvaniacarvalho19@hotmail.com; manuelasouza@ufrb.edu.br; darlene_hgt12@hotmail.com; dhilermandohora@hotmail.com; andrea@ufrb.edu.br

ABSTRACT: Defining the cardinal temperatures for germination in the scenario of climate change with prediction of an increased terrestrial temperature plays an important role in conserving plant resources. This study aimed to define the cardinal temperatures, the time of conducting germination tests, and to apply the thermal time model for seeds of Diospyros inconstans. Thermal screening was carried out, based on germination tests performed in BOD chambers, at constant temperatures of 10, 20, 25, 30 and $40^{\circ} \mathrm{C}$, under a photoperiod of 12 hours/light. The cardinal temperatures for germination of $D$. inconstans seeds are $26.7^{\circ} \mathrm{C}$ (optimal temperature), $13.8^{\circ} \mathrm{C}$ (minimum temperature) and $37.7^{\circ} \mathrm{C}$ (maximum temperature). Germination tests for the species can be conducted at optimum temperature, lasting 26 days for radicle emission and 63 days for formation of normal seedlings.

Key words: cardinal temperatures; forest species; jacú fruit; thermal time

\section{Dependência térmica da germinação de sementes de Diospyros inconstans Jacq. (Ebenaceae)}

RESUMO: A definição das temperaturas cardeais para a germinação de sementes, no cenário de mudanças climáticas com previsão de aumento da temperatura terrestre, assume importante função na conservação dos recursos vegetais. Neste estudo objetivou-se definir as temperaturas cardeais, o tempo de condução de testes de germinação e aplicar o modelo de tempo térmico para sementes de $D$. inconstans. $O$ screening térmico aplicado ao teste de germinação foi realizado nas temperaturas constantes de $10,20,25,30$ e $40^{\circ} \mathrm{C}$, sob fotoperíodo de 12 horas/luz. As temperaturas cardeais para germinação de sementes de $D$. inconstans são $26,7^{\circ} \mathrm{C}$ (temperatura ótima), $13,8^{\circ} \mathrm{C}$ (temperatura mínima) e $37,7^{\circ} \mathrm{C}$ (temperatura máxima). Os testes de germinação para a espécie podem ser realizados sob temperatura ótima, com duração de 26 dias para emissão da raiz primária e 63 dias para a formação de plântulas normais.

Palavras-chave: temperaturas cardeais; espécie florestal; fruta de jacú; tempo térmico 


\section{Introduction}

Responding to environmental changes is the essential seed ability to focus germination in the space-time, with the most suitable conditions for initial seedling establishment and subsequent development (Jiménez-Alfaro et al., 2016). Several environmental factors act as regulators of the germination process, such as water, temperature, and light. When soil moisture is not a limiting condition, the temperature turns into the main factor that determines the germination percentage and speed (Bewley et al., 2013).

There is a temperature range for each species in which the seeds are apt to germinate, which is defined by the minimum (Tb), optimum (To) and maximum (Tc) cardinal temperatures and is also related to the environmental conditions the species is adapted to (Alvarado \& Bradford, 2002; Bewley et al., 2013). Minimum and maximum temperatures are respectively the lowest and highest temperature at which germination is null, with the optimum temperature as the one where the germination is maximum and fastest (Bewley et al., 2013).

Mathematical models based on the concept of thermal time $(\theta)$ can describe the seed germination response to temperature. In these models, thermal time stands for the thermal energy amount that a given percentage of seeds needs to accumulate to germinate, expressed in degreedays units (Cardoso, 2011). Besides the descriptive function, thermal time approach can also be used to estimate the actual germination time at different temperatures (Daibes \& Cardoso, 2018), which is useful in determining the most suitable period for developing seed-based propagation actions.

Diospyros inconstans Jacq., popularly known as "jacú" fruit or "marmelinho", is a species of habit ranging from shrubby to arboreal, 2 to $10 \mathrm{~m}$ tall, native and with wide distribution over the Brazilian territory (Wallnöfer, 2015). This species is recommended for urban landscaping and heterogeneous reforestation composition due to its fruit attractiveness for fauna (Cipriane et al., 2017).

There are no records of studies in scientific literature on the cardinal temperatures for germination of $D$. inconstans, yet Cipriane et al. (2017) indicated the temperature of $25^{\circ} \mathrm{C}$ for germination tests with this species. Temperatures that promote germination for other species of this genus range from $20.5^{\circ} \mathrm{C}$ for Diospyros kaki L. (Peche et al., 2016) to $30^{\circ} \mathrm{C}$ for Diospyros ebenaster Retz (Oliveira et al., 2005).

Thereby, this study aimed to define the cardinal temperatures, the time for conducting germination tests, and to apply the thermal time model on the seeds of $D$. inconstans.

\section{Materials and Methods}

The experiment was conducted at the Laboratory of Ecology and Forest Restoration, at the Federal University of Recôncavo da Bahia, in Cruz das Almas campus, Bahia, Brazil.

$D$. inconstans seeds were obtained from mature fruits collected from 17 mother plants, in a clearing used for grazing located in the Environmental Protection Area of the Pedra do Cavalo Lake, in the Ipuaçú district, Feira de Santana, Bahia, Brazil (12²1'38.0 “S and 39 02'26.0”W), in November 2018. The climate of the region is of the Asa type, megathermal with a rainy period in winter and a dry one in summer, having mean annual temperature and average rainfall around $25.2{ }^{\circ} \mathrm{C}$ and $720.7 \mathrm{~mm}$, respectively (Santos et al., 2018). Table 1 displays the monthly temperature and rainfall data for the studied region.

Seeds processing took place manually in the laboratory, where they were washed under running water and placed in trays during three days for superficial drying under average temperature of $24.7{ }^{\circ} \mathrm{C}$ and relative humidity of $82 \%$, just before determination of the water content and setting up the experiment. Seed water content $(25.8 \%)$ was determined by the oven method at $105 \pm 3{ }^{\circ} \mathrm{C}$ for 24 hours, by using four replicates composed of four grams of seeds each (Brazil, 2009), with the results in percentage.

Thermal screening was performed in an entirely randomized experimental design with four replicates of 25 seeds per treatment, placed on paper towel rolls (germitest) moistened with distilled water at 2.5 times their dry weight (g) (Brazil, 2009). These rolls were packed in transparent plastic bags in order to minimize evaporation and then were placed in different germination chambers regulated at constant

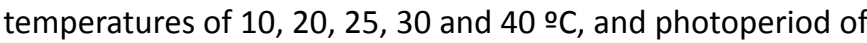
12 hours/light.

For 90 days, the number of hard, dead, and germinated seeds was counted, considering as criteria the primary root emission (Bewley et al., 2013), just as well as the number of normal and abnormal seedlings (Brazil, 2009). This count ended after all germinated seeds formed seedlings and, at the end of the experiment, the viability of hard seeds was confirmed by the $0.5 \%$ tetrazolium test, with the seed exposure time to the solution of 2 hours, under the temperature of $30^{\circ} \mathrm{C}$ (Silva et al., 2016).

The variables (random component) number of germinated seeds, dead and hard seeds obtained at different temperatures (systematic component) were analyzed by generalized linear models (GLM), with binomial distribution and logit link function (Carvalho et al., 2018). Inferences of the analysis

Table 1. Monthly records (1981-2010) of temperature (A) and rainfall (B) in Feira de Santana, Bahia, Brazil (INMET, 2019).

\begin{tabular}{|c|c|c|c|c|c|c|c|c|c|c|c|c|}
\hline & Jan & Feb & Mar & Apr & May & Jun & Jul & Aug & Seo & Oct & Nov & Dec \\
\hline Max temp. $\left({ }^{\circ} \mathrm{C}\right)$ & 32.5 & 327 & 32.5 & 30.4 & 28.5 & 26.7 & 26.2 & 27.7 & 28.5 & 30.5 & 31.9 & 32.6 \\
\hline Min. temp. $\left({ }^{\circ} \mathrm{C}\right)$ & 21.3 & 21.8 & 21.9 & 21.5 & 20.4 & 19.4 & 18.4 & 17.9 & 18.6 & 19.8 & 20.8 & 21.4 \\
\hline Mean temp. $\left({ }^{\circ} \mathrm{C}\right)$ & 26.1 & 26.3 & 26.3 & 25.2 & 23.8 & 22.5 & 21.8 & 21.7 & 22.8 & 24.4 & 25.5 & 26.0 \\
\hline Rainfall (mm) & 68.8 & 79.1 & 40.8 & 66.8 & 84.7 & 94.9 & 72.1 & 56.5 & 41.6 & 31.6 & 67.4 & 50.0 \\
\hline
\end{tabular}

In which: Max temp. = maximum temperature; Min. temp. = minimum temperature; Mean temp. = mean temperature. 
were based on the Chi-Square statistic, the data concerning the variables with significant effect were transformed into percentages, and lastly, the regression analysis was applied.

In order to determine the minimum time required to conduct the germination test on lots of $D$. inconstans seed, the germination and normal seedling formation curves were constructed for the $25{ }^{\circ} \mathrm{C}$ temperature, by fitting the nonlinear response-plateau regression (LPR) model. This model is a segmented nonlinear regression that assumes two segments, with the first one describing an increasing curve until a certain point of the ordinate, corresponding to the plateau; from this point, the ordinate assumes a constant value, which in turn corresponds to the second segment (Guimarães et al., 2013). This LRP model is given by: yi $\leftrightarrow\left(\beta_{0}+\beta_{1} \cdot x_{i}, x_{i} \leq \beta b ; \beta_{0}+\right.$ $\left.\beta_{1} \cdot \beta_{b}, x_{i}>\beta_{b}\right)$, where: $\beta_{0}$ is the intercept $(Y) ; \beta_{1}$ is germination increment rate; and $\beta_{b}$ is the break point. For values of $x$ greater than $\beta_{b}$, the function is constant and indicates the stabilization of germination, which was assumed as the minimum time required to conduct the germination test of seeds from the studied species. All data analyses were performed by employing the R software version 3.5.3 (R Core Team, 2019).

Modeling the thermal dependence of germination was in accordance to the equations proposed by Ellis et al. (1986) and Cardoso (2011), with some adaptations. This mentioned procedure was performed in three steps.

In step I, the cardinal temperatures were determined by the graphical method, in which the germination rate was calculated through the inverse of the mean time (Bewley et al., 2013) for the germination percentages of $10,20,30,40$, $50,60,70$ and $80 \%$, for each repetition, at each evaluated temperature. Afterwards, a regression model of germination rate as a function of the temperature was fitted for each germination percentage by GLM (Gaussian model and canonical linkage). Minimum points then defined both base and maximum temperatures while the maximum point, calculated in WolframAlpha software (2019), defined the optimum temperature.

In step II, the probit regression model was fitted for the suboptimal temperatures. To that end, cumulative germination percentages for each replicate at each temperature were transformed into probit $_{(\mathrm{g})}$ by the INV.NORM function in the Excel software (Cardoso, 2011) and fitted as a function of the logarithmic thermal time $(\log \theta g=[(\mathrm{T}-\mathrm{Tb}) \mathrm{tg})$, by the following model: PROBIT(g) = a $+\{\log [(\mathrm{T}-\mathrm{Tb}) \operatorname{tg}]\} / \sigma \Theta$ where: $\mathrm{a}$ is the intercept; $\mathrm{T}$ is the experimental temperature; $\mathrm{Tb}$ is the base temperature; $t_{g}$ is the germination time; and $\sigma \theta$ is the standard deviation of the thermal time. The Tb value used was the $\mathrm{Tb}$ values mean obtained by the minimum points during step I. After the fit, isolating the term $t_{g}$ from the model, the equation that estimates the expected time for a certain proportion of seeds to germinate at sub-optimal temperatures was obtained: $t_{\mathrm{g}}=\left[10^{\text {(probit(g)-a). } \sigma \theta}\right] /(\mathrm{T}-\mathrm{Tb})$.

In step III, the probit regression model was fitted for the supra-optimal temperatures. The used model was similar to the one used for sub-optimal temperatures, since the seed lot had approximate maximum temperature (Tc) among different subpopulations (Cardoso \& Pereira, 2009), with the difference being in the substitution of $\left[(T-T b) t_{g}\right]$ by $\left[(T c-T) t_{g}\right]$. After fitting the model, the equation that estimates, for supra-optimal temperatures, the time required for a given proportion of seeds to germinate was obtained: $\operatorname{tg}=\left[10^{\text {(probit(g)-a). } \cdot \theta}\right] /(\mathrm{Tc}-\mathrm{T})$.

Probit regression models were fitted in a nonlinear form by using generalized least squares and the iterative GaussNewton algorithm of the nlme package (Pinheiro et al., 2019), whose data analyses were performed using the R software version 3.5.3 (R Core Team, 2019).

\section{Results and Discussion}

Significance of the treatment effects, analyzed by generalized linear models and inference tests by Chi-Square, was verified for the number of germinated ( $p$-value $=0.01$ ), dead ( $p$-value<0.0001) and hard of ( $p$-value<0.0001) seeds.

Percentage of seed germination was at its maximum at the $27.8^{\circ} \mathrm{C}$ temperature and remained around $90 \%$ in the range of 25 to $30^{\circ} \mathrm{C}$, while when at lower or higher temperatures than this abovementioned range, it decreased progressively, with the lowest values expressed at 13.2 and $39.5^{\circ} \mathrm{C}$. When at the temperatures of 10 and $40{ }^{\circ} \mathrm{C}$, the germination was null. Hard seed percentage was higher at the lowest temperatures and reduced with the increasing temperatures until reaching the null value at $32.2^{\circ} \mathrm{C}$. However, under temperatures above 27.8 ${ }^{\circ} \mathrm{C}$, there was a sharp increase in the percentage of dead seeds, reaching up to $100 \%$ when at $40{ }^{\circ} \mathrm{C}$ (Figure 1), thus indicating that $D$. inconstans seeds are sensitive to high temperatures.

The temperature that provided better germination performance for $D$. inconstans (Figure 1 ) is within the expected for tropical forest species (Brancalion et al., 2010; Durr et al., 2015). Cipriani et al. (2017) evaluated D. inconstans germination at the temperatures of 25 and $30^{\circ} \mathrm{C}$, and based on their results, they recommended the $25{ }^{\circ} \mathrm{C}$ temperature for conducting germination tests for seeds from this species.

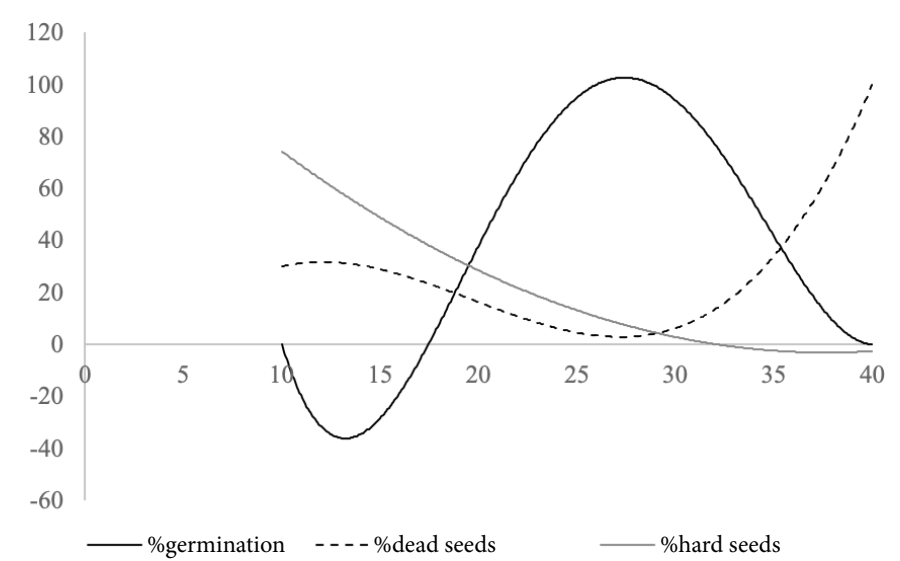

Figure 1. Percentage of seed germination $\left(\% g=0.0037 t^{4}\right.$ $\left.0.3969 t^{3}+14.681 t^{2}-214.14 t+1033.3 ; R^{2}=0.99 \%\right) ;$ percentage of dead seeds (\%dead $=0.0167 t^{3}-0.9814 t^{2}+16.405 t-52.6$; $\left.\mathrm{R}^{2}=0.9522\right)$ and percentage of hard seeds (\%hard $=0.101 \mathrm{t}^{2}-$ $7.6076 t+140.2 ; R^{2}=0.83$ ) of Diospyros inconstans Jacq. as a function of the temperature. 
Only the viable seeds were considered for calculating the percentage of hard seeds, according to the tetrazolium test, which was higher at lower temperatures and then reduced with the increasing temperatures until reaching zero at 32.2 ${ }^{\circ} \mathrm{C}$ (Figure 1). This result indicates that the germination was inhibited at lower temperatures, which agrees with MarcosFilho (2015), who reported that the occurrence of germination depends on a series of biochemical reactions, catalyzed by enzymes that have an optimum temperature range of operation; therefore, at temperatures below this range, the activity of these mentioned enzymes is reduced.

A sharp increase in the percentage of dead seeds took place at temperatures above $27.8{ }^{\circ} \mathrm{C}$, reaching up to $100 \%$ at $40{ }^{\circ} \mathrm{C}$ (Figure 1 ), thus evidencing that $D$. inconstans seeds are sensitive to these temperatures. Stress caused by high temperatures induces an increased production of species reactive to oxygen and a reduction in the antioxidant enzymes activity, resulting in the membrane lipids peroxidation and ultimately the seed death (Santos et al., 2017).

Dispersal of $D$. inconstans seeds in the Pedra do Cavalo Lake APA is between September (Mendonça et al., 2018) and November, which corresponds to mid-spring period. This region has two rainy periods, the first one in autumn-winter and the second one during late spring. Thus, the response of the seeds from this species to high temperatures suggests that the most favorable period for germination, in this region, is during autumn-winter, when the temperatures are milder (Table 1). However, D. inconstans seeds can be exposed to soil moisture conditions, which are favorable for germination, soon after their dispersal, when the temperature rises (Santos et al., 2018). In November, the maximum temperature can reach up to $31.9{ }^{\circ} \mathrm{C}$ when associated with a rainfall index greater than $60 \mathrm{~mm}$ (Table 1), that way the $D$. inconstans seeds dispersed at this time will have a lower probability of success.

Finding that germination of $D$. inconstans seeds can be negatively affected at high temperatures alerts to the risk of compromising the regeneration of populations of this species in the Pedra do Cavalo Lake protection area. Unfortunately, the current context of increasing deforestation and clearings, which contributes to the increase in soil temperature, added to global warming (IPCC, 2015), further increasing the elimination risk to this species in the aforementioned protection area. Cochrane et al. (2014) reported some of the soil warming impacts, such as the reduction and delay of seedling emergence for shrub species of the genus Banksia (Proteaceae).

The germination curve of the regression response-plot for data corresponding to the $25{ }^{\circ} \mathrm{C}$ temperature, closer to the optimum, demonstrates that seed germination in this species starts at 10 days and stabilizes at 25 , considering only the protrusion of the primary root (Figure 2), while the formation of normal seedlings starts at 34 days and stabilizes at 63 (Figure 3).

Estimated cardinal temperatures by fitting the germination rate curves, based on different proportions of germinated seeds, were the following: minimum temperature of $13.81^{\circ} \mathrm{C}$, maximum of $37.63^{\circ} \mathrm{C}$, and optimum of $26.64{ }^{\circ} \mathrm{C}$ (Table 2). The obtained temperature threshold from this modeling is close to the one estimated by the germination percentage curve (Figure 1), being in agreement with the expected for native forest species (Durr et al., 2015).

Occurrence of a relatively constant base temperature among the different germination percentages, as observed in the present study, has been reported for several species (Alvarado \& Bradford, 2002; Cardoso \& Pereira, 2009; Daibes \& Cardoso, 2018; Derakhshan et al, 2018). When base temperature is constant, thermal time models assume that seed fractions germinate at different times due to variations in the required thermal time amount for each percentage of seeds to germinate (Cardoso, 2011).

At the supra-optimal range, many studies have indicated variations in the maximum temperature and constant thermal time among different germination percentages (Alvarado \& Bradford, 2002; Daibes \& Cardoso, 2018; Derakhshan et al.,

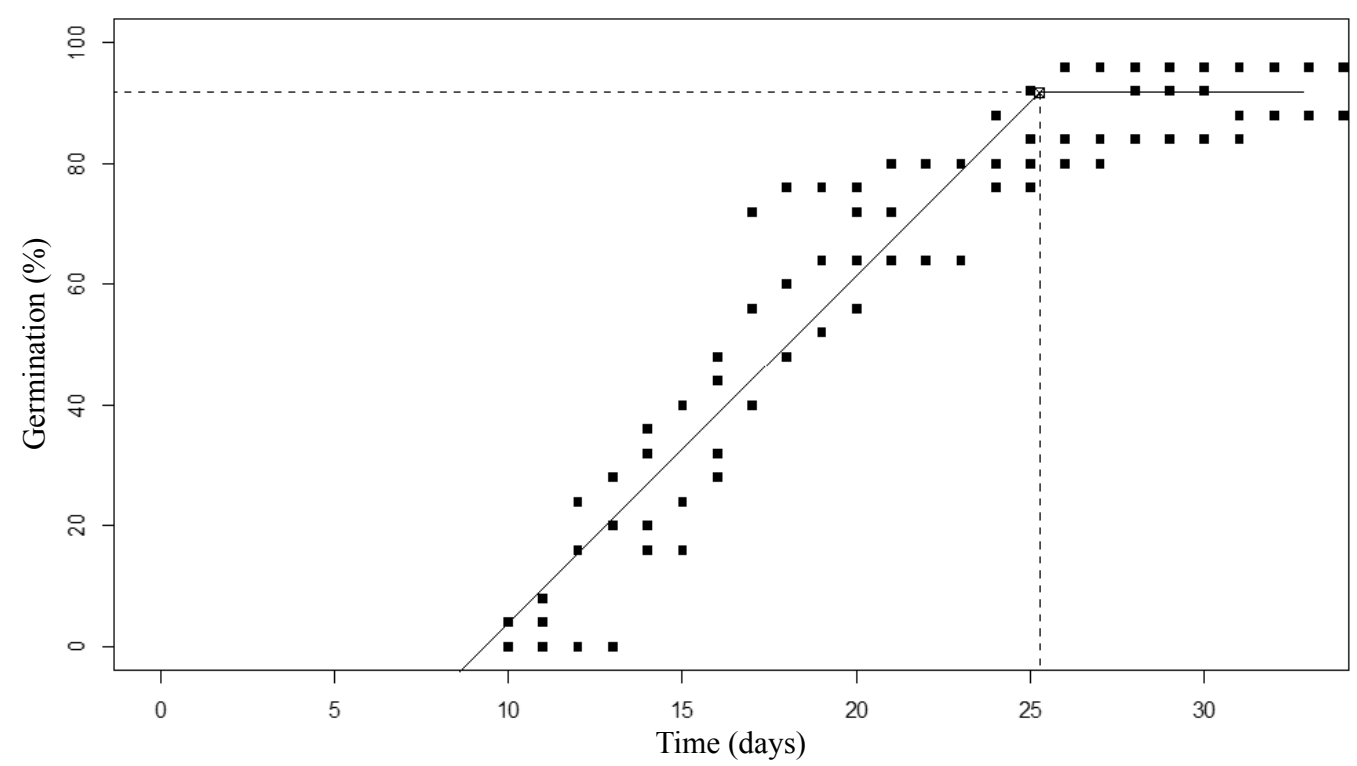

Figure 2. Germination curve of Diospyros inconstans Jacq. seeds as a function of time, fitted by the response-plot regression $\left(R^{2}=0.93\right)$. 


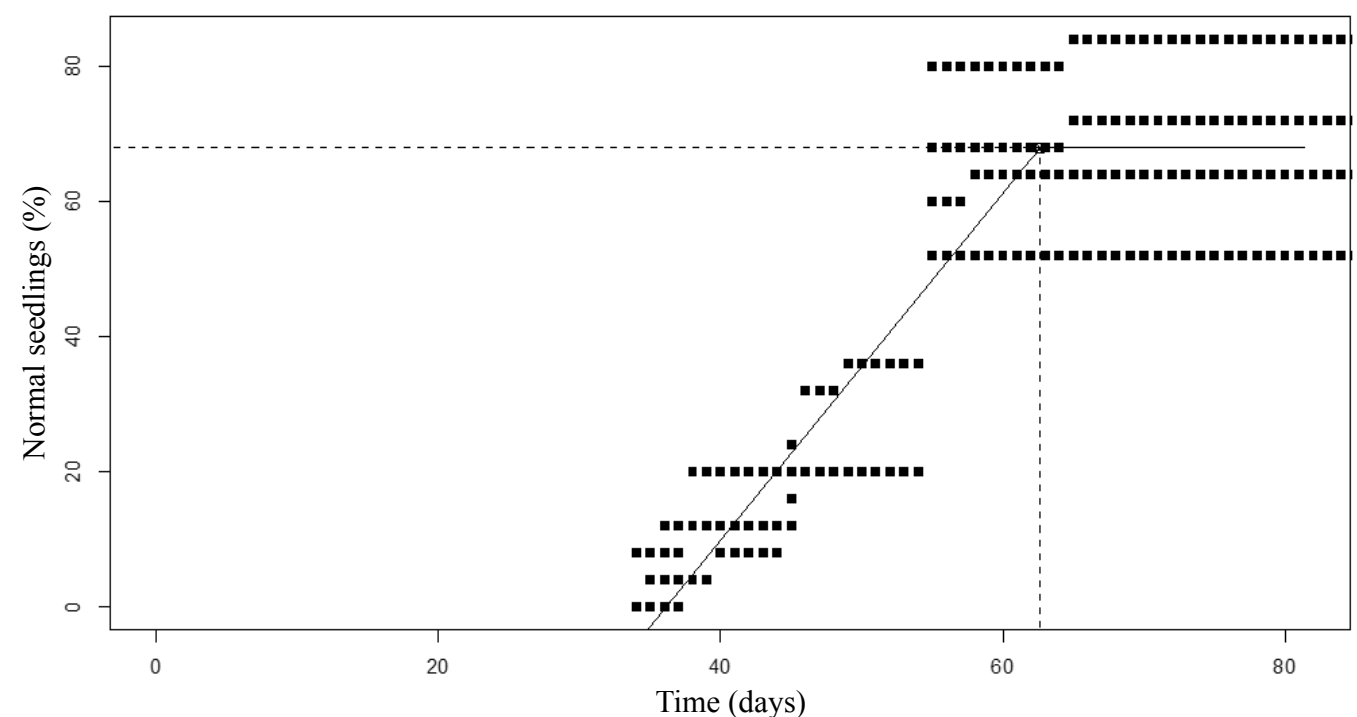

Figure 3. Curve of normal seedling formation of Diospyros inconstans Jacq. as a function of time, fitted by the response-plat equation $\left(R^{2}=0.81\right)$

Table 2. Fitted equations for germination rate $(\mathrm{tg})$ as a function of temperature for different germination percentages of Diospyros inconstans Jacq.

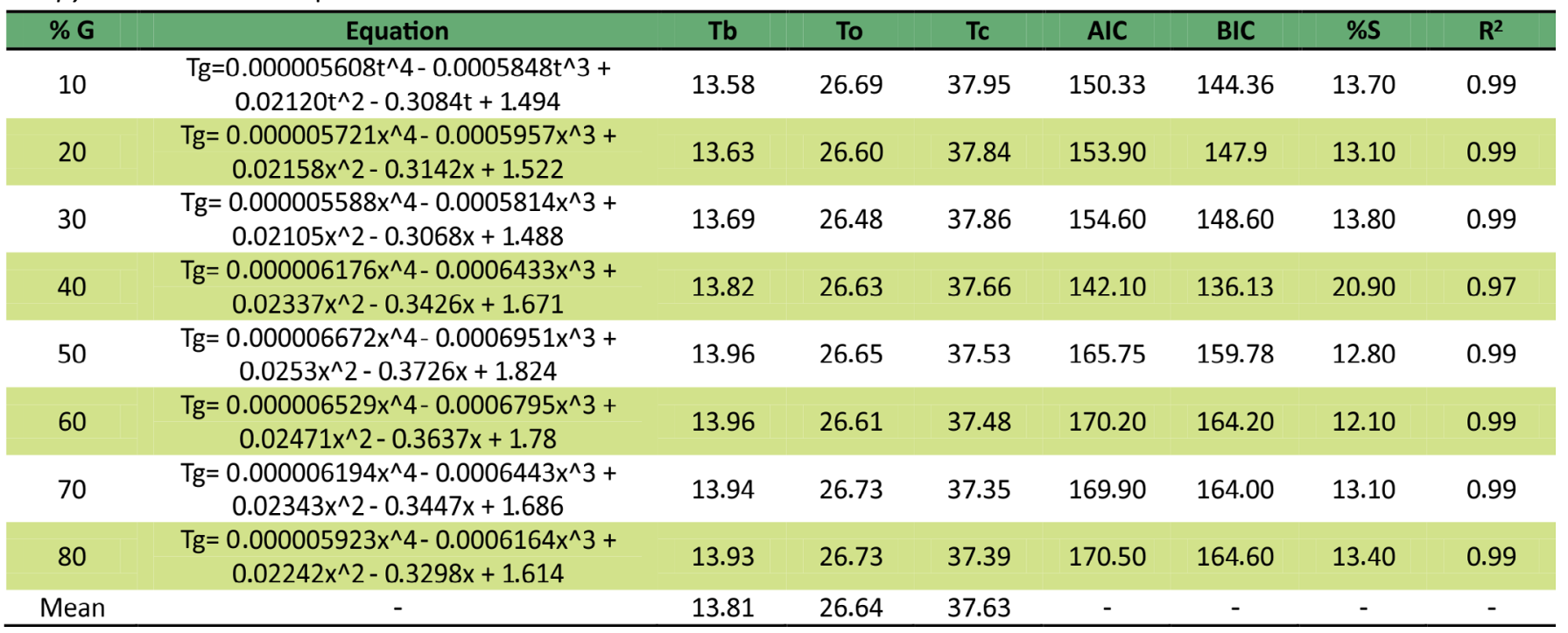

Where: $\% \mathrm{G}=$ germination percentage; $\mathrm{Tb}=$ minimum temperature; $\mathrm{To}=$ optimum temperature; $\mathrm{TC}=$ maximum temperature; $\mathrm{AIC}=\mathrm{Akaike}$ information criteria; $\% \mathrm{~S}=$ standard deviation in percentage; $\mathrm{BIC}=$ Bayesian Schwarz criterion.

2018). In this case, this variation among germination times is attributed to the difference between maximum and experimental temperatures (Cardoso, 2011). For D. inconstans seeds, maximum temperature as well as base temperature were stable for different germination percentages, similar to results found by Cardoso \& Pereira (2009) for Drymaria cordata (L.) seeds.

According to the fitting obtained (Table 3 ) to estimate the time required for a given proportion of seeds to germinate $\left(\mathrm{t}_{\mathrm{g}}\right)$, among sub-optimal temperatures $\left(13.8^{\circ} \mathrm{C}<\mathrm{T} \leq 26.6^{\circ} \mathrm{C}\right)$ the following equation can be used: $\left.T_{g}=\left[10^{(\% g-(-397.3))^{*} 0.0053}\right)\right] /(T-$ 13.81), where, \%g = germination proportion that is the desired to estimate the time; and $T$ is the temperature for which it is desired to evaluate the germination behavior. For supraoptimal temperatures $\left(26.6^{\circ} \mathrm{C}<\mathrm{T}<37.6^{\circ} \mathrm{C}\right)$ the equation that estimates the time required for a given proportion of seeds to germinate is: $\mathrm{T}_{\mathrm{g}}=\left[10^{\left.(\% \mathrm{~g}-(-407.3))^{*} 0.0053\right)}\right] /(37.6-\mathrm{T})$.
Figure 4 illustrates the estimated time from the equations for $50 \%$ germination of seeds subjected to temperatures between 15 and $36{ }^{\circ} \mathrm{C}$. In the sub-optimal and supraoptimal ranges, the closer the germination temperature is to the optimal temperature, the faster the germination will happen.

According to the model, for occurring 10,50 , and $80 \%$ of germination at $25{ }^{\circ} \mathrm{C}, 13,20$, and 30 days are required, respectively. Experimentally, these percentages were obtained at the estimated time or a few days earlier (Table 4). However, by observing germination at 20 and $30{ }^{\circ} \mathrm{C}$, it was possible to attest that the model tends to underestimate or overestimate when under temperatures other than $25^{\circ} \mathrm{C}$.

In a study with thermal time models, conducted by using different populations of Peltophorum dubium (Spreng) species, Daibes \& Cardoso (2018) obtained good germination 
Table 3. Parameters of the probit regression model to describe germination of Diospyros inconstans Jacq. seeds at sub-optimal and supra-optimal temperatures.

\begin{tabular}{|c|c|c|c|c|}
\hline \multirow[b]{2}{*}{ Parameters } & \multicolumn{2}{|c|}{ Sub-optimal } & \multicolumn{2}{|c|}{ Supra-optimal } \\
\hline & Value & $\begin{array}{c}\text { IC } \\
(\mathrm{LI} / \mathrm{LS})\end{array}$ & Value & $\begin{array}{c}\text { IC } \\
\text { (LI/LS) }\end{array}$ \\
\hline$A$ & -397.32 & $-429.8 /-364.8$ & -407.3 & $-440.54 /-374.07$ \\
\hline$\sigma \Theta$ & 0.0052651 & $0.00488 / 0.005649$ & 0.005265 & $0.004882 / 0.005648$ \\
\hline$\% S$ & \multicolumn{2}{|c|}{10.4} & \multicolumn{2}{|c|}{10.4} \\
\hline$R^{2}$ & \multicolumn{2}{|c|}{0.99} & \multicolumn{2}{|c|}{0.99} \\
\hline AIC & \multicolumn{2}{|c|}{143.4} & \multicolumn{2}{|c|}{143.4} \\
\hline $\mathrm{BIC}$ & \multicolumn{2}{|c|}{146.8} & \multicolumn{2}{|c|}{146.8} \\
\hline
\end{tabular}

Where: $\mathrm{a}=$ intercept, $\sigma \Theta=$ thermal time standard deviation, $\% \mathrm{~S}=$ standard deviation pattern, $\mathrm{R}^{2}=$ coefficient of determination, $\mathrm{AIC}=\mathrm{Akaike}$ information criteria; $\mathrm{BIC}=\mathrm{Bayesian}$ Schwarz criterion, IC = intervals of confidence, $\mathrm{LI}=$ lower limit, LS = upper limit.

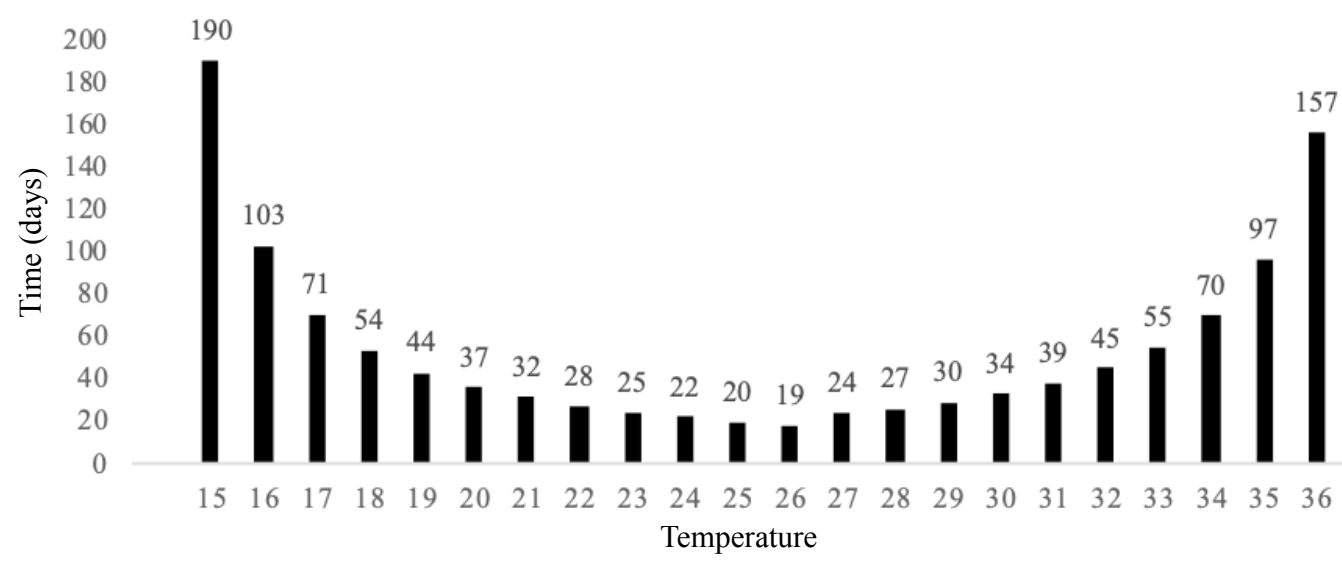

Figure 4. Time required for $50 \%$ twinning of Diospyros inconstans Jacq. seeds under different temperature conditions.

Table 4. Observed and estimated time by the probit model, for occurrence of 10,50 and $80 \%$ germination of Diospyros inconstans Jacq. seeds at three different temperatures.

\begin{tabular}{ccccccc}
\hline \multirow{2}{*}{$\begin{array}{c}\text { Temperature } \\
\left({ }^{\circ} \mathrm{C}\right)\end{array}$} & \multicolumn{2}{c}{$t_{10}$ (days) } & \multicolumn{2}{c}{$t_{50}$ (days) } & \multicolumn{2}{c}{$t_{80}$ (days) } \\
\cline { 2 - 7 } & Observed & Expected & Observed & Expected & Observed & Expected \\
\hline 20 & 56 & 23 & - & - & - & 24 \\
25 & 13 & 13 & 18 & 20 & 30 & 24 \\
30 & 16 & 21 & 24 & 34 & 29 & 50 \\
\hline
\end{tabular}

Where: $t_{10}=$ time for occurring $10 \%$ of germination; $t_{50}=$ time for occurring $50 \%$ of germination e $t_{80}=$ time for occurring $80 \%$ of germination.

time estimates for different temperatures, yet also found some limitations such as underestimation or overestimation of times, mainly at lower temperatures.

There was no germination at the experimental temperatures of 10 and $40{ }^{\circ} \mathrm{C}$, therefore the modeling was based on data from the temperatures of 20,25 , and $30{ }^{\circ} \mathrm{C}$, which may have impaired the performance of the equations for temperatures other than $25^{\circ} \mathrm{C}$. Hence, it is recommended increasing the number of experimental temperatures within the range between the minimum $\left(13.81{ }^{\circ} \mathrm{C}\right)$ and maximum $\left(37.63^{\circ} \mathrm{C}\right)$ temperatures indicated for the species in order to obtain thermal time models of higher accuracy. Furthermore, to validate the model, future research could also evaluate its predictive ability under field conditions.

\section{Conclusions}

Cardinal temperatures for germination of $D$. inconstans seeds are $13.8{ }^{\circ} \mathrm{C}$ (minimum), $26.7^{\circ} \mathrm{C}$ (optimum), and $37.7^{\circ} \mathrm{C}$ (maximum).
Germination tests with $D$. inconstans seeds can be conducted at optimum temperature, lasting 26 days for primary root protrusion and 63 days for the formation of normal seedlings.

\section{Compliance with Ethical Standards}

Author contributions: Conceptualization: ESC, AVRM; Formal analysis: AVRM; Funding acquisition: AVRM, MOS; Investigation: ESC, DPS, MDHS; Methodology: ESC, AVRM; Project administration: AVRM; Resources: AVRM, MOS; Supervision: AVRM; Visualization: ESC, MOS, AVRM; Writing - original draft: ESC, MOS, AVRM; Writing - review \& editing: ESC, MOS, AVRM.

Conflict of interest: We have no conflict of interest that may influence the article.

Funding: Coordination for the Improvement of Higher Education Personnel - Brazil (CAPES) - Financing Code 001 Institute of Environment and Water Resources (INEMA). 


\section{Literature Cited}

Alvarado, V.; Bradford, K.J. A hydrothermal time model explains the cardinal temperatures for seed germination. Plant Cell and Environment, v.25, n.8, p.1061-1069, 2002. https://doi. org/10.1046/j.1365-3040.2002.00894.x.

Bewley, J.D.; Bradford, K.; Hilhorst, H.W.M.; Nonogaki, H. Seeds: Physiology of Development, Germination and Dormancy, 3.ed. New York: Springer Science, 2013. 408p.

Brancalion, P.H.S.; Novembre, A.D.L. C.; Rodrigues, R. R. Temperatura ótima de germinação de sementes de espécies arbóreas brasileiras. Revista Brasileira de Sementes, v.32, n.4, p.15-21, 2010. https://doi.org/10.1590/S0101-31222010000400002.

Brasil. Ministério da Agricultura, Pecuária e Abastecimento, Secretaria de Defesa Agropecuária. Regras para análise de sementes. Brasília: MAPA/ACS, 2009. 399p. https://www.gov.br/agricultura/ pt-br/assuntos/insumos-agropecuarios/arquivos-publicacoesinsumos/2946_regras_analise_sementes.pdf. 09 Apr. 2020.

Cardoso, V.J.M. Metodologia para análise da dependência térmica da germinação pelo modelo de graus-dia. Oecologia Australis, v.15, n.2, p.236-248, 2011. https://doi.org/10.4257/oeco.2011.1502.04.

Cardoso, V.J.M.; Pereira, F.J.M. Dependência térmica da germinação de sementes de Drymaria cordata (L.) Willd. ex Roem. \& Schult. (Cariophyllaceae). Acta Botanica Brasilica, v.23, n.2, p.305-312, 2009. https://doi.org/10.1590/S0102-33062009000200002.

Carvalho, F.J; Santana, D.G; Araújo, L.B. Why analyze germination experiments using Generalized Linear Models? Journal of Seed Science, v.40, n.3, p.281-287, 2018. https://doi. org/10.1590/2317-1545v40n3185259.

Cipriani, V.B.; Lima, B.M.; Garlet, J.; Ebumeo, L. Seed sanity of Diospyros Inconstans Jacq. Australian Journal of Basic and Applied Sciences, v.11, n.11, p.41-47, 2017. http://www.ajbasweb.com/ old/ajbas/2017/August/41-47.pdf. 29 Mar. 2020.

Cochrane, A.; Hoyle, G.L.; Yates, C.J.; Wood, J.; Nicotra, A.B. Predicting the impact of increasing temperatures on seed germination among populations of Western Australian Banksia (Proteaceae). Seed Science Research, v.24, n.3, p.195-205, 2014. https://doi. org/10.1017/S096025851400018X.

Daibes, L.F.; Cardoso, V.J. Seed germination of a South American forest tree described by linear thermal time models. Journal of Thermal Biology, v.76, p.156-164, 2018. https://doi.org/10.1016/j. jtherbio.2018.07.019.

Derakhshan, A.; Bakhshandeha, A.; Siadata, S.A.; Moradi-Telavata, M.; Andarzian, S. B. Quantifying the germination response of spring canola (Brassica napus L.) to temperature. Industrial Crops and Products, v.122, p.195-201, 2018. https://doi.org/10.1016/j. indcrop.2018.05.075.

Durr, C; Dickie, J.B; Yang, X.Y; Pritchard, H. W. Ranges of critical temperature and water potential values for the germination of species worldwide: Contribution to a seed trait database. Agricultural and Forest Meteorology, v.200, p.222-232, 2015. https://doi.org/10.1016/j.agrformet.2014.09.024.

Ellis, R.H.; Covell, S.; Roberts, E.H.; Summerfield, R.J. The influence of temperature on seed germination rate in grain legumes. II. Intraspecific variation in chickpea (Cicer arietinum L.) at constant temperatures. Journal of Experimental Botany, v.17, n.183, p.1503-1515, 1986. https://doi.org/10.1093/jxb/37.10.1503.
Guimarães, G.C; Rosa, S.D.V.F; Coelho, L.F.S; Veiga, A.D; Clemente, A.C.S. Minimum period to assess the potential of germination of coffee seeds. Journal of Seed Science, v.35, n.3, p.347-352, 2013. https://doi.org/10.1590/S2317-15372013000300011.

Instituto Nacional de Meteorologia - INMET. Dados meteorológicos. Tempo. https://tempo.inmet.gov.br. 20 Dec. 2019.

Intergovernmental Panel on Climate Change - IPCC. Climate Change 2014: Synthesis Report. Contribution of Working Groups I, II and III to the Fifth Assessment Report of the Intergovernmental Panel on Climate Change. Geneva: IPCC, 2015. 151p. http://www.ipcc. ch/report/ar5/syr. 29 Mar. 2020.

Jiménez-Alfaro, B.J.; Silveira, F.A.O.; Fidelis, A.; Poschold, P.; Commander, L.E. Seed germination traits can contribute better to plant community ecology. Journal of Vegetation Science, v.27, n.3, p.637-645, 2016. https://doi.org/10.1111/jvs.12375.

Marcos-Filho, J. Fisiologia de sementes de plantas cultivadas. 2 ed. Londrina: Abrates, 2015. 660p.

Mendonça, A.V.R.; Souza, J.S.; Souza, M.O.; Santos, J.P.A. Propagação de espécies florestais nativas da Bahia: uma contribuição para conservação das APAs de Joanes-Ipitanga e Lago Pedra do Cavalo. Cruz das Almas: Editora UFRB, 2018. 422p.

Oliveira, M. Inez; Cavalcante, L.; Hebert, I.; Beckmann, M. Z.; Martins, A. B. G. Temperatura na germinação de sementes de Sapota Preta. Revista de Biologia e Ciências da Terra, v.5, n.2, 2005, p.1-7. http://www.cpatsa.embrapa.br/public_eletronica/downloads/ OPB1807.pdf. 09 Apr. 2020.

Peche, P. M.; Barbosa, C. M. A.; Pio, R.; Sousa, P. H. A.; Valle, M. H. Estratificação das sementes, ácido giberélico e temperatura na obtenção de porta-enxertos de caquizeiros. Revista Ciência Agronômica, v.47, n.2, p.387-392, 2016. https://doi. org/10.5935/1806-6690.20160046.

Pinheiro, J; Bates, D; DebRoy, S; Sarkar, D. nlme: linear and nonlinear mixed effects models. R packageversion 3.1-141, 2019. https:// CRAN.R-project.org/package=nlme. 29 Mar. 2020.

R Development Core Team: a language and environment for statistical computing. Vienna: R Foundation for Statistical Computing, 2019. https://www.r-project.org. 29 Mar. 2020.

Santos, M. M.; Borges, E. E. L.; Aaíde, G. M.; Souza, G. A. Germination of seeds of Melanoxylon brauna Schott. under Heat stress: production of reactive oxygen species and antioxidant activity. Forests, v. 8 , n. 405 , p. 1-13, 2017. https://doi.org/10.3390/ f8110405.

Santos, R.A.; Martins, D.L.; Santos, R.L. Balanço hídrico e classificação climática de Köppen e Thornthwaite no município de Feira de Santana (BA). Geo UERJ, n.33, 2018. https://doi.org/10.12957/ geouerj.2018.34159.

Silva, B.A; Nogueira, J.L; Vieira, E.S.N; Panobianco, M. Critérios para condução do teste de tetrazólio em sementes de araucária. Pesquisa Agropecuária Brasileira, v.51, n.1, p.61-68, 2016. https://doi.org/10.1590/S0100-204X2016000100008.

Wallnöfer, B.A revision of neotropical Diospyros (Ebenaceae): part 8. Annalen des Naturhistorischen Museums in Wien. Serie B für Botanik und Zoologie, v.117, p.151-218, 2015. https://www.jstor. org/stable/43922313?seq=1. 30 Apr. 2020. 